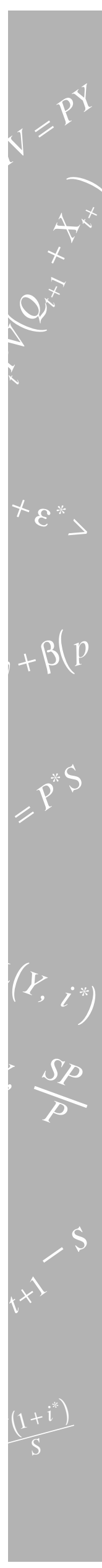

IMF Staff Papers

Vol. 48, No. 1

(C) 2001 International Monetary Fund

\title{
Welfare Effects of Uzbekistan's Foreign Exchange Regime
}

\author{
CHRISTOPH B. ROSENBERG and MAARTEN DE ZEEUW ${ }^{*}$
}

In addition to transferring about 16 percent of GDP from exporters to importers, Uzbekistan's quasi-fiscal multiple exchange rate regime generates identifiable welfare losses of 2-8 percent of GDP on import markets and up to 15 percent on export markets. These excess burdens have increased substantially with the growing difference among exchange rates. The welfare analysis allows some conclusions regarding the optimal reform strategy: (i) welfare losses will decline overproportionally as exchange rates unify, (ii) exchange rate unification should be supplemented by changing the explicit fiscal system; (iii) at a minimum, Uzbekistan would benefit from moving to an explicit fiscal regime. [JEL F31, H29]

n January 1997, Uzbekistan formally (re)introduced a system of multiple exchange rates and restrictions on current account transactions with the aim of promoting import substituting industries, protecting foreign exchange reserves, and subsidizing basic food imports. Several recent studies have dealt with the effects of this system on sectoral distribution, foreign investment, and macroeconomic stability. ${ }^{1}$ However, its consequences for economic efficiency and welfare, while acknowledged, have so far received little attention. This paper, which builds on an earlier article by Rosenberg, Ruocco, and Wiegard (1999), tries to address this question. Specifically, it attempts to identify and quantify the substantial microeconomic distortions on export and import markets that result from the exis-

\footnotetext{
${ }^{*}$ The authors would also like to thank Galina Kostina for excellent research assistance and Leif Hansen, Bob Flood, Tom Wolf, Jorge Marquez-Ruarte, Oleh Havrylyshyn, Christian Mumssen, and an anonymous referee for helpful comments. All remaining errors are ours.

${ }^{1}$ See World Bank (1999), IMF (1998), IMF (2000).
} 
tence of at least three distinct exchange rates in Uzbekistan. This analysis also shows how a simple exercise in welfare economics can provide insights into the appropriate sequencing of reforms. The approach presented here may thus serve as a blueprint for structural policies aiming at the removal of distortions in general.

\section{Uzbekistan's Foreign Exchange Regime Since 1996}

Uzbekistan is one of only a few transition countries ${ }^{2}$ that operates a segmented foreign exchange market and multiple exchange rates, in connection with strict controls of export and import markets. After a period of foreign exchange and trade liberalization in 1995-96, this system was first created as an emergency measure in response to growing balance of payment pressures following an unexpected deterioration of the country's terms-of-trade position. Since then, the authorities have justified the continued-and intensified-use of current account restrictions with a need to direct resources from traditional exports (such as cotton, gold, minerals) to the development of a capital-intensive, import-substituting industrial base (for example, automobiles, energy, chemistry) and to subsidize socially important consumer good imports. The foreign exchange regime has thus become the cornerstone of the so-called "Uzbek model of development," which emphasizes a dominant role of the state during the transition process. More fundamentally, this system emerged in response to a general lack of market reforms, especially in the fiscal sphere.

In practice, Uzbekistan's foreign exchange market is split into three segments: ${ }^{3}$ two official and one unofficial. In 1997, the largest segment was the so-called auction market at the Uzbek Republican Currency Exchange (URCE). In this market, the government determines administratively an appreciated exchange rate, well below the market clearing level. Since at this rate, demand for foreign exchange exceeds supply, the government has to restrict access and enforce supply. The supply of foreign exchange to the URCE mainly derives from the mandatory surrender of all foreign exchange proceeds from "centralized exports," in particular gold and cotton fiber, which make up about two-thirds of the country's total export earnings. On the demand side, the Republican Monetary Commission (RMC) decides who may buy foreign exchange at the URCE and how much. Access to the auction market rate is granted to certain importers of capital goods, raw materials, grains, and some high-priority consumer goods, as well as enterprises servicing foreign loans guaranteed by the government. Requests for foreign exchange have to be submitted by selected banks on behalf of their clients. The government itself also acquires foreign exchange at the URCE, mainly in order to service its own external debt. Starting in mid-1998,

\footnotetext{
${ }^{2}$ Among the countries of the Baltics, Russia, and other countries of the former Soviet Union, only Turkmenistan applies foreign exchange regimes similar to that of Uzbekistan.

${ }^{3}$ Strictly speaking, the description of the foreign exchange regime covers only the period from January 1998 to June 2000. On July 1, 2000, and July 1, 2001, the authorities introduced a number of measures that further segmented the foreign exchange market. These changes are not covered by this paper. They do not, however, alter the substance of the analysis.
} 
access to this market became somewhat more restricted (at least by law). Commercial banks were generally granted access to the URCE at the more depreciated commercial bank exchange rate (see below) with the profit from the exchange rate difference accruing to the central bank.

The second official segment of Uzbekistan's foreign exchange market is the commercial bank market, where commercial banks and exchange bureaus trade foreign exchange with other banks, enterprises, and individuals. Formally, the commercial exchange rate is freely determined, but in practice, it is administratively set by the government below the market clearing level. Until mid-1998, this rate was not allowed to deviate by more than 12 percent from the auction market exchange rate, but following a decree of July $1,1998,{ }^{4}$ this margin has been adjusted upward.

In response to excess demand at this appreciated rate, the government also restricts access and enforces supply in this market. On the supply side, exporters in 1997 and 1998 had to surrender 30 percent of all foreign exchange proceeds from decentralized (that is, non-gold and non-cotton fiber) exports. Effective January 1, 1999, the surrender requirement was increased to 50 percent. The mandatory surrender had to be at the more appreciated auction rate until July 1 , 1998 but is now at the commercial bank rate. In this connection, the buy/sell spread for commercial banks has been reduced to about 3 percent from 12 percent. In addition, the Central Bank of Uzbekistan (CBU) sells foreign exchange to commercial banks from the 100 percent surrender for centralized exports; in doing so, the CBU benefits from the growing spread between the auction rate and the commercial bank rate (see Box 1). On the demand side, only a limited number of traders are permitted to buy foreign exchange at the commercial bank market, and they need to obtain a special license and a foreign exchange quota from the RMC. Individuals are only allowed to purchase small amounts of foreign exchange for a very limited number of purposes, such as pilgrimages or authorized study abroad.

An inevitable consequence of these strict regulations of official markets for foreign exchange is the emergence of an unofficial (illegal) curb market for foreign exchange. The exchange rate on this market is largely determined by the demand that cannot be satisfied on the two official markets. Therefore, the curb market premiums reflect, inter alia, the extent to which access to the official markets is restricted. The mark-up for foreign exchange on the domestic curb market was about 100 percent until mid-1998, but has since increased to more than 400 percent (see Figure 1).

In addition, there is a non-cash offshore curb market where the exchange rate is up to 50 percent more depreciated than at the domestic curb market, due to the existence of cash withdrawal restrictions in Uzbekistan's banking system. The size of this market, however, is unknown, and it is less observable than the other three. For the sake of simplicity, this market segment is excluded from the remaining analysis.

${ }^{4}$ Presidential Decree UP-2010, "On Measures to Further Develop and Liberalize the Off-Auction Foreign Exchange Market." 


\section{Box 1. Quasi-Fiscal Operations Through the Central Bank}

The decree of July 1, 1998 opened a new source of profit for the CBU, as it was now allowed to buy foreign exchange at the auction rate and sell it at the more depreciated commercial banks' exchange rate. In conventional accounting terms, this profit is recorded in the capital accounts of the CBU's balance sheet. These are augmented every time the CBU sells foreign exchange to a licensed importer or a commercial bank. Ceteris paribus, these foreign exchange operations have reduced the growth of reserve money as the CBU withdrew money from the economy by implicitly taxing exporters. They, therefore, acted as an automatic stabilizer within a rather loose monetary policy.

This accounting profit ${ }^{1}$ only partly reflects the quasi-fiscal operation incurred by a central bank in a situation with a parallel market-determined exchange rate. In economic terms, the central bank makes an implicit profit or loss every time it buys or sells foreign exchange at the artificially appreciated exchange rate (see, for example, Agénor and Ucer, 1995, pp. 26-27). This is because the true market clearing exchange rate more accurately reflects the true marginal value of foreign exchange than the overvalued official exchange rates. Thus, there is an implicit tax (subsidy) associated with the central bank's foreign exchange operations if it is a net buyer (seller) of foreign exchange. This holds even in a situation where the central bank sells foreign exchange at the same rate as it buys it.

The table below summarizes the CBU's quasi-fiscal operations due to the existence of multiple exchange rates, including buying and selling foreign exchange at below market rates. To do this, one needs to estimate the true market exchange rate, and here we choose a weighted average of the existing exchange rates using the relative share of the three market segments.

\begin{tabular}{|c|c|c|c|c|c|c|}
\hline & \multicolumn{2}{|c|}{1997} & \multicolumn{2}{|c|}{1998} & \multicolumn{2}{|c|}{1999} \\
\hline & 1st half & $2^{\text {nd }}$ half & $1^{\text {st }}$ half & $2^{\text {nd }}$ half & $1^{\text {st }}$ half & $2^{\text {nd }}$ half \\
\hline & \multicolumn{6}{|c|}{ (In millions of U.S. dollars) } \\
\hline CBU inflows & 894 & 1,292 & 938 & 1,125 & 729 & 784 \\
\hline Gold production & 392 & 359 & 341 & 339 & 323 & 337 \\
\hline Centralized exports (mainly cotton) & 502 & 933 & 596 & 786 & 406 & 446 \\
\hline CBU outflows & 1,441 & 1,501 & 1,095 & 982 & 984 & 576 \\
\hline $\begin{array}{l}\text { CBU direct sales for } \\
\text { priority purposes } \\
\text { CBU sales to commercial banks }\end{array}$ & $\begin{array}{r}1,441 \\
0\end{array}$ & $\begin{array}{r}1,501 \\
0\end{array}$ & $\begin{array}{r}1,095 \\
0\end{array}$ & $\begin{array}{l}502 \\
480\end{array}$ & $\begin{array}{l}503 \\
481\end{array}$ & $\begin{array}{l}402 \\
174\end{array}$ \\
\hline & \multicolumn{6}{|c|}{ (In millions of sum, unless otherwise indicated) } \\
\hline Balance of implicit taxes $(+)$ & & & & & & \\
\hline and subsidies (-) & $-11,934$ & $-4,908$ & $-4,817$ & 14,293 & $-19,558$ & 46,616 \\
\hline (as a percentage of GDP) & -3.8 & -0.8 & -1.0 & 1.5 & -2.7 & 3.4 \\
\hline $\begin{array}{l}\text { Because of different legal } \\
\text { exchange rates }\end{array}$ & 0 & 0 & 0 & 6,941 & 11,481 & 7,995 \\
\hline $\begin{array}{l}\text { Because of buying/selling below } \\
\text { estimated market clearing } \\
\text { exchange rate }\end{array}$ & $-11,934$ & $-4,908$ & $-4,817$ & 7,352 & $-31,039$ & 38,621 \\
\hline Memorandum item: & & & & & & \\
\hline $\begin{array}{l}\text { Estimated market clearing exchange } \\
\text { rate (average, sum per U.S. dollars) }\end{array}$ & 80 & 98 & 116 & 156 & 237 & 320 \\
\hline
\end{tabular}

Source: CBU; and authors' own calculations.

${ }^{1}$ The accounting profit can be calculated as the difference between the two exchange rates multiplied by the amount of foreign exchange sold. See Mackenzie and Stella (1996), pp. 20-21. 
Figure 1. Uzbekistan: Exchange Rates, April 30, 1996-January 1, 2000

(In sum/US\$)

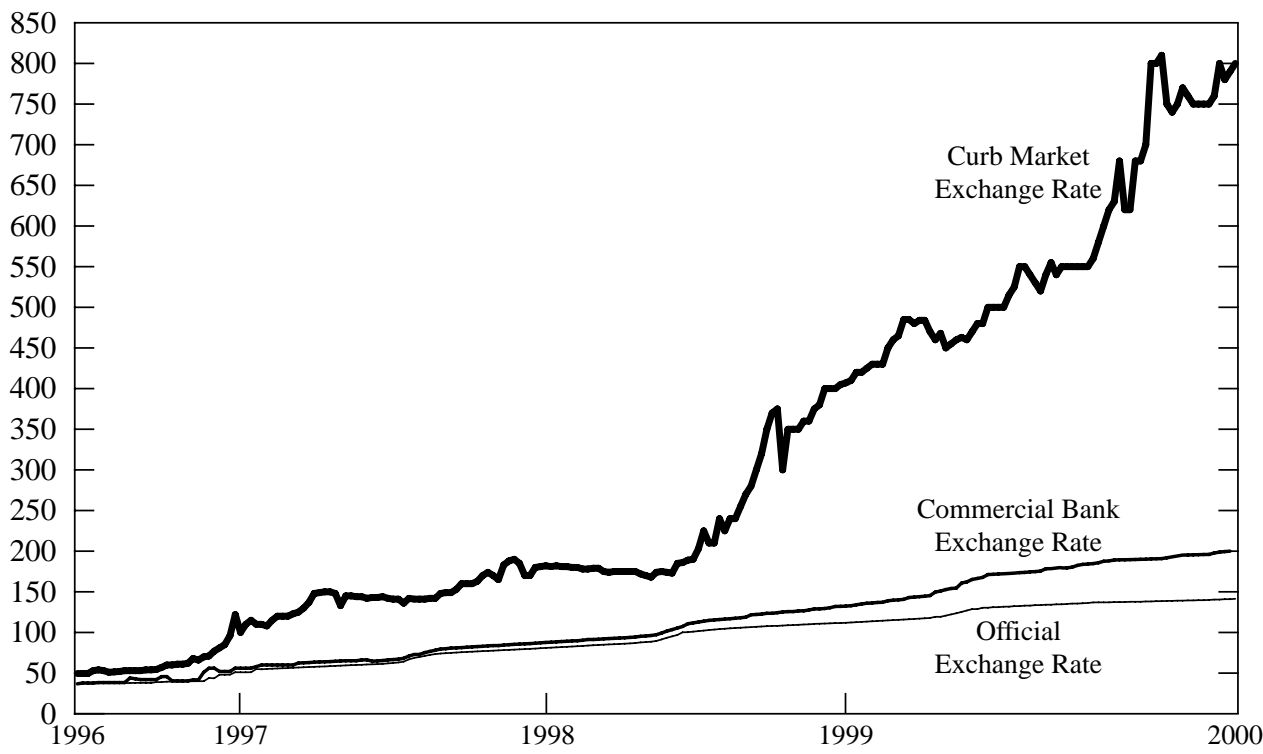

Sources: CBU, IMF, staff estimates.

Figure 2 shows foreign exchange flows in Uzbekistan's two official markets in the three years following the introduction of convertibility restrictions in late 1996. Total inflows declined because low commodity prices (especially for gold and cotton) in combination with the overvalued official exchange rate, convertibility restrictions, and a general deterioration of the business climate led to a decline in exports and foreign direct investment, as well as an increase in unofficial capital outflows. As one can see from Figure 2, the government reacted to this trend by curtailing currency conversions for imports and by drawing down foreign assets. In addition, there were substantial unrecorded foreign exchange transactions on the illegal curb market. One estimate by the World Bank (1999, p. 113) puts purchases on this market segment in 1997 at some US $\$ 1.4$ billion or 26 percent of all foreign exchange sales, excluding capital account transactions (Table 1$).^{5}$

The shares of the three market segments have shifted markedly since 1996. Following the essence of the decree in July 1998, some foreign exchange purchases were moved from the auction market (at the official exchange rate) to the commercial bank market (at the commercial bank exchange rate). The curb

${ }^{5}$ Sales of foreign exchange may in fact be higher, as households and enterprises build up cash foreign exchange assets. Persistently high inflation rates, restrictions in the banking system, and negative real interest rates discourage savings in national currency. 
Figure 2. Foreign Exchange Flows through the Banking System (In millions of U.S. dollars)
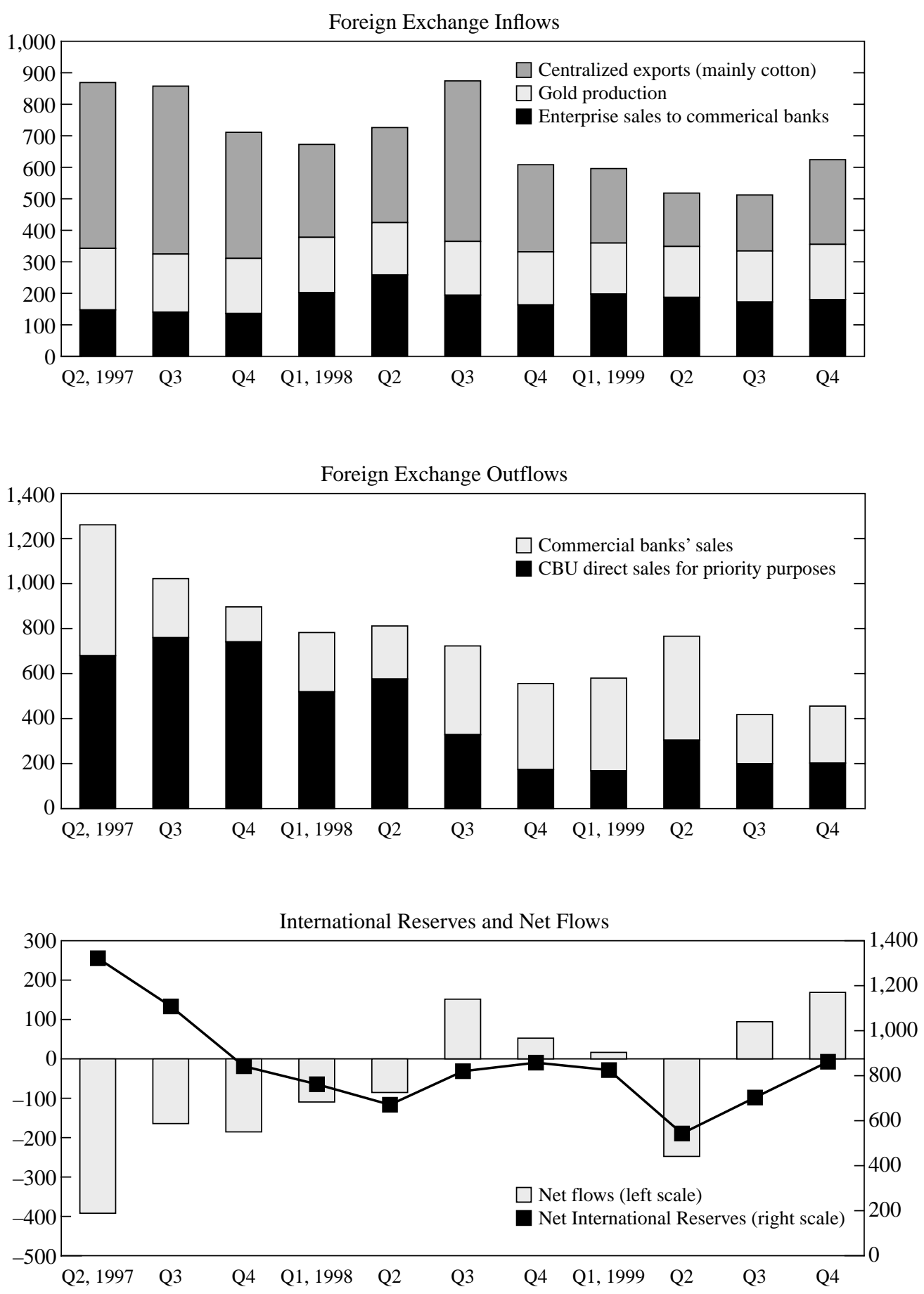

Sources: CBU, authors' own calculations. 


\section{Table 1. Uzbekistan: Average Exchange Rates and Market Shares, 1997-99 \\ (In sums per U.S. dollar)}

\begin{tabular}{lcccccc} 
& \multicolumn{3}{c}{ Average Exchange Rates } & \multicolumn{3}{c}{ Estimated Market Share } \\
& $\begin{array}{c}\text { Auction } \\
\text { market } \\
\text { (CBU) }\end{array}$ & $\begin{array}{c}\text { Commercial } \\
\text { bank market }\end{array}$ & $\begin{array}{c}\text { Curb } \\
\text { market }^{1}\end{array}$ & $\begin{array}{c}\text { Auction } \\
\text { market } \\
\text { (CBU) }\end{array}$ & $\begin{array}{c}\text { Commercial } \\
\text { bank market }\end{array}$ & $\begin{array}{c}\text { Curb } \\
\text { market }\end{array}$ \\
& & & & & & \\
& & & & & & \\
1997 & 67 & 75 & $150(124 \%)$ & 55 & 19 & 26 \\
1998 & 95 & 105 & $270(184 \%)$ & 39 & 31 & 30 \\
1999 & 125 & 163 & $540(334 \%)$ & 26 & 39 & 35
\end{tabular}

Sources: CBU; World Bank (1999), p. 113; and authors' own calculations.

${ }^{1}$ Curb market premium in parentheses.

market probably gained importance as tightened convertibility restrictions led more and more importers to purchase foreign exchange illegally. ${ }^{6}$

\section{Quasi-Fiscal Operations Through the Foreign Exchange Regime}

Governments can collect revenues and redistribute income among sectors and household groups by means other than explicit taxes and subsidies. Such activities are usually referred to as quasi-fiscal operations because they are fiscal in all but name although they are often carried out by central banks and other public financial institutions. ${ }^{7}$ The Uzbek authorities use a wide range of such mechanisms, including multiple currency practices, inflation tax, subsidized and directed lending, non-remunerated reserve requirements and credit ceilings, price interventions in product markets, and wage regulation. Of these, the multiple currency regime is probably the most significant—although it is in the nature of quasi-fiscal operations that they cannot be easily quantified. According to one study (IMF, 1998, pp. 58-68), the array of implicit taxes and subsidies related to multiple currency practices amounted to almost 13 percent of GDP in 1997, if one assumes a hypothetical market clearing rate for that year of sum 100 per U.S. dollar. As will be shown below, the size of these government activities increased in the years 1998-99, as the difference between the official exchange rates and the true market clearing rate widened. In addition, the changes introduced in July 1998 made the system more complex with regard to the CBU's quasi-fiscal operations (see Box 1).

\footnotetext{
${ }^{6}$ Since no estimates of the size of the curb market in 1998 and 1999 are available, it is assumed to have increased slightly to 35 percent of all transactions. Note, however, that this assumption influences the calculation of the indicative exchange rate, the U.S. dollar denominated GDP, and ultimately the size of the welfare effects described below.

${ }^{7}$ For a survey of quasi-fiscal operations in general, see Mackenzie and Stella (1996).
} 
In this paper, we concentrate on the immediate impact of multiple exchange rates on legal export and import markets alone, that is, we abstract from their side effects on illegal trade, households, banks, and the budget. These are partly dealt with in IMF (1998, pp. 58-68) and World Bank (1999, pp. 17-24).

The quasi-fiscal impact of Uzbekistan's multiple exchange rate regime on exporters and importers arises from the difference between the administratively set official exchange rate and the true market clearing exchange rate (that is, the rate that would emerge in the absence of all current account restrictions). Exporters that are forced to sell their foreign exchange earnings at the overvalued official exchange rate pay an implicit tax. Conversely, importers that are allowed to buy foreign exchange rate at the official exchange rate are granted an implicit subsidy. ${ }^{8}$ Table 2 shows the implicit tax rate applying to (legal) exports and the implicit subsidy applying to (legal) imports for 1997-99. The indicative (equilibrium) exchange rate is calculated as the weighted average of the three existing exchange rates, using the market shares shown in Table 1 . This is, of course, only a rough approximation of the true market clearing rate, which would depend on factors beyond the scope of this paper. However, the indicative exchange rate may suffice to illustrate the magnitude of transfers and distortions involved.

Not surprisingly, implicit tax and subsidy rates applying to foreign trade operations more than doubled with the increase of the curb market premium that started in the summer of 1998. Note, however, that the implicit tax rate on noncentralized exports is much lower than that on centralized exports both because the more depreciated commercial bank exchange rate applies and only a part of foreign exchange receipts needs to be surrendered.

The size of the quasi-fiscal transfer between exporters and importers can be calculated by comparing the domestic currency equivalent of foreign exchange flows based on actually applied exchange rates with those based on the market clearing rate. Table 3 shows that producers of centralized exports are the main losers, paying an implicit tax to the tune of 12 percent of GDP in 1999, while the recipients of foreign exchange through official channels gained about 15 percent of GDP. Both the implicit tax and subsidy burden have increased over the last three years, despite the fact that the U.S. dollar value of foreign trade declined. In 1997, the subsidy for imports was higher than the tax on exports because the CBU drew down net reserves. After the changes to the foreign exchange regime in July 1998, the CBU moved from being a net loser to becoming a net gainer, which explains why for 1998 as a whole implicit taxes exceeded implicit subsidies. This trend continued in 1999, especially after the CBU substantially reduced its foreign exchange sales in the second half of the year (see Box 1).

Note that in addition to the transfer from legal exports to legal imports examined here, there is an equivalent implicit subsidization of illegal exports and implicit taxation of illegal imports, which benefit (suffer) from the overly depreciated curb market exchange rate. The size of this transfer cannot be quantified since the size of these illegal transactions is unknown. It can be assumed, however,

${ }^{8}$ For a numerical example illustrating the functioning of Uzbekistan's quasi-fiscal regime see Rosenberg and De Zeeuw (2000, p. 10). 


\begin{tabular}{|c|c|c|c|}
\hline \multicolumn{4}{|c|}{$\begin{array}{c}\text { Table 2. Uzbekistan: Implicit Tax } \\
\text { and Subsidy Rates on Foreign Trade, 1997-99 } \\
\text { (In percent, unless otherwise indicated) }\end{array}$} \\
\hline & 1997 & 1998 & 1999 \\
\hline \multicolumn{4}{|l|}{ Implicit tax rates } \\
\hline Centralized exports & 26 & 37 & 56 \\
\hline Other exports & 5 & 9 & 21 \\
\hline \multicolumn{4}{|l|}{ Implicit subsidy rates } \\
\hline Centralized imports & 26 & 37 & 56 \\
\hline Other imports & 17 & 30 & 43 \\
\hline \multicolumn{4}{|l|}{ Memorandum items: } \\
\hline Surrender requirement on non-centralized exports & 30 & 30 & 50 \\
\hline Official exchange rate (sum/U.S. dollar, average) & 67 & 95 & 125 \\
\hline Commercial banks' exchange rate (sum/U.S. dollar, average) & 75 & 105 & 163 \\
\hline Curb market exchange rate (sum/U.S. dollar, average) & 150 & 270 & 540 \\
\hline Indicative exchange rate (sum/U.S. dollar, average) & 90 & 151 & 285 \\
\hline
\end{tabular}

that this set of quasi-fiscal transfers has increased with the widening of the exchange rate premium and the rise of the shadow economy.

Quasi-fiscal operations through the foreign exchange regime not only redistribute resources between sectors. As is the case with any government intervention that distorts relative prices, they also cause efficiency losses. In practice, these are manifested in many different ways: resources are diverted from sectors where Uzbekistan is likely to have a comparative advantage (for example, food and food processing) to large loss-making investments (such as the automobile industry); entrepreneurs spend more time thinking about how to circumvent cumbersome foreign exchange restrictions than how to improve their businesses; those companies who obtain import permissions sell their product at home or abroad at curbmarket equivalent prices, reaping large profit margins; and barter trade increases since foreign exchange is unavailable.

In principle, the welfare effects of Uzbekistan's foreign exchange regime are the same as an equivalent explicit system of taxes and subsidies. For example, the government could levy an export tax equivalent to the difference between the official exchange rate and the hypothetical market clearing rate on centralized exports. Nevertheless, direct government interventions, such as price regulations, combined with outright rationing cause larger microeconomic distortions than interventions such as explicit taxes. The size of these excess burdens of multiple exchange rate practices is the subject of Section III.

The equivalence of explicit and implicit government intervention also applies to the welfare-theoretical argument that the government is unlikely to be sufficiently informed about consumers' preferences and investors' profits to make deci- 


\begin{tabular}{|lrr} 
Table 3. Uzbekistan: Implicit Taxes and Subsidies \\
on Foreign Trade, 1997-99 \\
(In percent of GDP)
\end{tabular}

Sources: CBU; and authors' own calculations.

sions on the Pareto-optimal ranking of imports. Nevertheless, the Uzbek authorities do not justify their market interventions by the existence of negative market externalities, but rather insist that the government knows better than the private sector what imports benefit the country, especially in the long term. ${ }^{9}$

Before turning to the exact nature and size of the welfare losses associated with Uzbekistan's foreign exchange regime, let us review the reasons why an explicit fiscal regime would be preferable to the implicit system practiced now.

First, the present system suffers from a lack of transparency. Because of the hidden nature of quasi-fiscal operations, policy makers as well as voters have no clear picture of the existence of the tax or subsidy, its size, and the extent to which it was intended by the government. There is little accountability, putting the system at odds with a main principle of democratic administration. For example, the rules determining eligibility for currency conversion are established without a mandate by parliament. In a sense, implicit taxation is similar to tax evasion where the taxpayer does not report that he should pay tax-implicit taxation means that the government does not report that it is taxing.

Secondly, quasi-fiscal operations through the foreign exchange regime confine the government's flexibility when conducting fiscal policies. While revenues from explicit taxation can be saved or spent on the provision of public and merit goods, which are recognized to be a welfare-neutral form of public expenditure, implicit tax "revenues" from Uzbekistan's foreign exchange regime cannot be used for anything but the subsidization of certain industries. Thus, the system automatically generates distortions both on the revenue and expenditure side. The size of implicit subsidies, moreover, is determined arbitrarily by the

\footnotetext{
${ }^{9}$ See, for example, the following quote from an Uzbek government publication: "There is also great demand for foreign currency from shuttle traders importing consumer goods of unknown firms, without quality certificates. This cannot be considered sound from an economic point of view. Currency regulations, including restrictions on convertibility, prevent the influx of such goods" (Chepel, 1998).
} 
amount of implicit tax revenues that are funding them. An explicit import subsidy combined with a free market for foreign exchange would not have these drawbacks.

Third, multiple exchange rate practices entail a considerable administrative burden. Issuing foreign exchange licenses and quotas is not only a costly and inefficient use of the government's administrative resources, it also invites corruption and rent-seeking behavior. ${ }^{10}$ This is particularly the case if, as seen in Uzbekistan, many different agencies and officials are involved in the approval process. One of the macroeconomic implications is that such a cumbersome and corruption-prone system discourages foreign direct investment and exports, thus putting further pressure on the balance of payments.

Finally, multiple exchange rate practices introduce an element of uncertainty regarding the availability of foreign exchange. This encourages dollarization ${ }^{11}$ with all its associated problems for the sustainability of the banking system and monetary policy (see Baliño, Bennett, and Borensztein, 1999). More generally, it impedes planning by economic agents and implicitly imposes a risk premium to doing business in Uzbekistan.

\section{The Welfare Costs of Multiple Exchange Rates}

In this section we attempt to identify and quantify some of the welfare losses associated with Uzbekistan's foreign exchange regime. As shown in Section II, there is no difference from the welfare analytical point of view between the effects of explicit and implicit taxes and subsidies. We can, therefore, use standard trade theory when analyzing the welfare costs associated with the quasi-fiscal operations, which is the subject of this paper. For simplicity, we abstract from other distortions in these markets, such as state procurement at below-market prices and government subsidies for inputs. ${ }^{12} \mathrm{We}$ also omit an analysis of the welfare effects arising from the implicit subsidization of illegal exports and implicit taxation of illegal imports mentioned above. A formal variant of the model (described in the appendix) allows us to calculate the actual size of the net welfare losses involved, depending on some rough parameterizations.

\section{Theoretical Considerations}

The welfare effects of taxes and subsidies are typically examined in a static partial equilibrium model of an open economy using the concept of consumer and producer surpluses, the so-called Harberger triangles. A graphical exposition can be found in any standard textbook on foreign trade. For an application to the case of Uzbekistan's quasi-fiscal foreign exchange operations, see Rosenberg, Ruocco,

\footnotetext{
${ }^{10}$ As a result, Uzbekistan's consistently ranks low in international comparisons of transparent business practices, such as the Corruption Perception Index published by Transparency International.

${ }^{11}$ Demonetization in Uzbekistan is evidenced by the decline of the ratio of broad money to GDP from about 14 percent in 1996 to less than 10 percent in 1999.

${ }^{12}$ These are partly analyzed in Rosenberg, Ruocco, and Wiegard (1999).
} 
and Wiegard (1999). A similar analysis for Poland in the late 1980s was conducted by Tarr (1990).

First, consider the welfare effects on the exports side. If Uzbekistan is modeled as a small open economy (that is, it is a price taker for all of its exports), it faces a horizontal excess demand curve from the rest of the world. By imposing an implicit export tax (equivalent to the difference between world market prices at the official and the market clearing exchange rate), the government gains some implicit revenue in the form of cheap foreign exchange. On the other hand, the implicit export tax causes economic distortions and leads to a decrease of the producer surplus. In the small country case, the latter unambiguously outweighs the increase in consumer surplus and the country (on balance) loses economic welfare.

This may change if Uzbekistan is modeled as a sufficiently large exporter, for example, of cotton fiber. In this case, the country faces an upward sloping rather than horizontal excess world demand function. By imposing an implicit export tax and hence curtailing its own supply of cotton to world markets, Uzbekistan could tilt the terms of trade of cotton in its own favor and gain welfare at the expense of the rest of the world. In theory, the authorities could set an "optimal" exchange rate differential (equivalent to an optimal export tax) where the welfare gain and the implicit tax revenue outweigh the domestic distortions. The exact result will depend on the elasticities of demand and supply. When setting such an optimal export tax, the authorities may also want to take into account possible retaliations from trading partners as well as the size of the welfare cost imposed on the rest of the world. The latter may be of particular importance if Uzbekistan desires admission to the World Trade Organization.

Does Uzbekistan indeed have some monopolistic power on world cotton markets that would allow it to affect the international terms of trade in its favor? In the 1997-98 harvest season, Uzbekistan had a share in world exports of cotton fiber of about 15 percent (second after the United States) and a share in world production of about 6 percent, suggesting that it may indeed have some leverage to drive up world market prices by keeping its crop in stock. In practice, however, the country is very much dependent on the foreign exchange earned from its cotton crop and has therefore shown no signs that it is deliberately curtailing its supply. On the contrary, the authorities have made the increase of cotton yields one of their main priorities. Finally, the empirical evidence of the last few years does not seem to support a role for Uzbekistan as a price maker: while cotton production in Uzbekistan has steadily fallen, so have world cotton prices. We can therefore safely ignore the case of Uzbekistan as a large country.

Now consider the implicit subsidy granted to those importers who have access to foreign exchange at the preferential exchange rates. Again, Uzbekistan loses welfare if modeled as a small, price taking country for imports. In the unlikely event that Uzbekistan can be considered a "large country" (maybe for the import of specialized capital goods, such as cotton harvesting machines), the standard model leads to the conclusion that it unequivocally loses net welfare. This is because the improvement of the terms of trade for imported machinery is more 
than compensated by the loss of producer surplus due to subsidization. If the country wanted to use its market power, it should tax, not subsidize, certain capital goods imports.

\section{Quantitative Analysis}

The net welfare effects of implicit taxation and subsidization can be quantified by using a standard partial equilibrium model. For simplicity, consider the more realistic case of Uzbekistan as a small open economy, both for exports and imports. We assume a constant elasticity export supply function.

$$
P^{X}=B X^{\beta} \quad \beta>0
$$

with $P^{X}$ the export price (measured in foreign currency units) and $X$ the exported quantity and the export elasticity defined as

$$
\varepsilon_{X P}=\frac{d X}{d P^{X}} \frac{P^{X}}{X}=\frac{1}{\beta}
$$

After a number of manipulations, which are shown in the appendix, the net welfare losses can be expressed as a function of implicit tax revenues and elasticities. Unfortunately, no estimates of the latter exist for Uzbekistan or a similar transition country. Recent research by Reinhart (1995) and Senhadji and Montenegro (1999) suggest that long-run export elasticities in resource-rich developing countries are around or below unity, while they tend to be higher for industrial countries. Tarr (1990) uses a long-run elasticity of 1.16 in his study of pre-liberalization Poland. In the absence of a firm estimate, we examine a range of elasticities between 0.5 and 1.5 .

Table 4 shows the net welfare losses in 1997-1999 as a percent of GDP for these alternative export supply elasticities. Overall, welfare losses increase with export elasticities, which is in line with the Ramsey rule. Most importantly, our calculations show that welfare losses have increased more than proportionally during the past three years. ${ }^{13}$ As the difference between the administered exchange rates and the true market clearing exchange rate has widened, Uzbekistan's foreign trade has become increasingly distorted and inefficient. This is, inter alia, reflected in the decline of foreign trade and the low quality of government-subsidized investments ("white elephants").

The sensitivity analysis shows that for a plausible range of parameter values the welfare loss for centralized exporters is much larger than for other exporters facing a lower implicit tax burden. This is the case even if we assume that for centralized exports (mainly cotton and gold) the elasticity is less than unity, which

\footnotetext{
${ }^{13}$ This confirms a standard result in the theory of taxation. See for example Connolly and Munro (1999, pp. 196-202).
} 
WELFARE EFFECTS OF UZBEKISTAN'S FOREIGN EXCHANGE REGIME

Table 4. Uzbekistan: Net Welfare Losses on Exports Markets, 1997-99

\begin{tabular}{|c|c|c|c|}
\hline & 1997 & 1998 & 1999 \\
\hline \multirow[t]{2}{*}{ Centralized exports } & \multicolumn{3}{|c|}{ Implicit tax rate (in percent) } \\
\hline & 26 & 37 & 56 \\
\hline Elasticity & \multicolumn{3}{|c|}{ Net welfare loss (in percent of GDP) } \\
\hline 0.5 & 0.42 & 1.09 & 3.22 \\
\hline 1.0 & 0.88 & 2.34 & 7.47 \\
\hline 1.5 & 1.42 & 3.88 & 13.49 \\
\hline \multirow[t]{2}{*}{ Other exports } & \multicolumn{3}{|c|}{ Implicit tax rate (in percent) } \\
\hline & 5 & 9 & 21 \\
\hline Elasticity & \multicolumn{3}{|c|}{ Net welfare loss (in percent of GDP) } \\
\hline 0.5 & 0.01 & 0.06 & 0.29 \\
\hline 1.0 & 0.02 & 0.13 & 0.59 \\
\hline 1.5 & 0.04 & 0.20 & 0.94 \\
\hline
\end{tabular}

Sources: CBU; and authors' own calculations.

seems more likely, certainly in the short term. ${ }^{14}$ The results highlight the need to address the overvaluation of the official exchange rate and the 100 percent surrender requirement for cotton and gold producers. Unifying only the curb market exchange rate with the commercial banks' exchange rate, as the authorities did on May 1, 2000 does little to reduce the efficiency losses entailed by Uzbekistan's foreign exchange regime.

The calculation of the welfare effects of subsidizing imports is analogous to the export side. Table 5 shows the results, again for a range of plausible parameter values. ${ }^{15}$ As on the export side, the net welfare loss increased more than proportionally as the implicit subsidy rates more than doubled over the past three years. While in 1997 the total welfare loss due to these subsidies was less than 2 percent of GDP, it was in the range of 2 to 8 percent of GDP in 1999.

Note that in general one cannot simply add up the excess burdens from Table 4 and Table 5, not even if expressed in monetary terms. The reason is that the two distortions partly overlap each other, for instance when the subsidization of

\footnotetext{
${ }^{14}$ One may argue that the short-term supply elasticity of cotton is close to zero since inputs provided under the government procurement system are fixed and state orders aim at maximizing production irrespective of world prices. In practice, however, farmers have resorted to illegal exports in order to avoid the implicit taxation through the overvalued exchange rate. Therefore, their surrenders of cotton to the government for legal exports (which are captured here) in effect depend on the producer price in foreign currency terms.

${ }^{15}$ In the absence of elasticity data for Uzbekistan we again rely on recent estimates for developing countries as benchmark. Reinhart (1995) calculated a mean import demand elasticity of -0.66 for a sample of 11 developing countries in 1970-91, while Senhadji (1998) found a mean elasticity of -1.24 from a sample of 23 developing countries in 1960-93. In several developing countries their values are substantially larger, which is why we also explore an import demand elasticity of -2.0 .
} 
Table 5. Uzbekistan: Net Welfare Losses on Imports Markets, 1997-99

\begin{tabular}{|c|c|c|c|}
\hline & 1997 & 1998 & 1999 \\
\hline \multirow[t]{2}{*}{ Centralized imports } & \multicolumn{3}{|c|}{ Implicit subsidy rate (in percent) } \\
\hline & 26 & 37 & 56 \\
\hline Elasticity & \multicolumn{3}{|c|}{ Net welfare loss (in percent of GDP) } \\
\hline 0.5 & 0.52 & 0.72 & 1.44 \\
\hline 1.0 & 0.98 & 1.33 & 2.51 \\
\hline 2.0 & 1.79 & 2.32 & 3.99 \\
\hline \multirow[t]{2}{*}{ Other imports } & \multicolumn{3}{|c|}{ Implicit subsidy rate (in percent) } \\
\hline & 17 & 30 & 43 \\
\hline Elasticity & \multicolumn{3}{|c|}{ Net welfare loss (in percent of GDP) } \\
\hline 0.5 & 0.07 & 0.37 & 1.11 \\
\hline 1.0 & 0.13 & 0.69 & 2.01 \\
\hline 2.0 & 0.25 & 1.24 & 3.42 \\
\hline
\end{tabular}

Sources: CBU; and authors' own calculations.

exporters partly compensates for the implicit tax imposed on them. Some other caveats are in place when drawing conclusions from these calculations: the additional welfare effects from implicitly taxing and subsidizing illegal trade are omitted; export and import markets are not independent from one another; consumer and producer surpluses are of limited importance in the case of multiple price changes; and results may change if Uzbekistan is modeled as a large open economy, especially on the export market for cotton. Finally, the standard "second best" argument holds.

\section{Conclusions and Policy Implications}

This paper focuses on the welfare effects associated with the multiple exchange rate practices in Uzbekistan. ${ }^{16}$ An analysis of the implicit tax on centralized exports and the implicit subsidy on preferential imports shows that in 1999 there was a (measurable) net transfer of about 16 percent of GDP from exporters to importers. For plausible elasticity values, the efficiency loss caused by this quasifiscal operation is between 2 and 8 percent of GDP for importers and up to 15 percent of GDP for exporters, but may be much larger if the distortions in the growing illegal trade are included. The welfare loss is especially strong for central-

\footnotetext{
${ }^{16}$ In addition, Uzbekistan's foreign exchange regime has implications for economic equity. The implicit tax on centralized exports (mainly cotton) is regressive, as it levies a heavy burden on the poorest part of the population, those working in agriculture. The same applies to the expenditure side: social assistance through price regulation is not targeted to the poor, but extended to all consumers of certain commodities, including the higher income groups. Moreover, rationing of scarce capital or foreign exchange is usually associated with favoritism and outright discrimination.
} 
ized exports of cotton and gold, the sectors which are faced with the most unfavorable exchange rates. With increasing implicit subsidy rates (measured by the difference between the official and hypothetical market clearing rate), the welfare loss on the import side is limited to the amount actually spent on imported goods. With increasing implicit tax rates, the welfare loss on the export side increases with the elasticity of export supply and is theoretically unlimited. Welfare losses may be somewhat smaller if Uzbekistan has some monopolistic power on the world cotton market.

Several policy conclusions arise from our analysis. First, Section II showed that even if the welfare effects of explicit and implicit taxes and subsidies are the same, there are several reasons why an explicit fiscal system would be preferable. These include considerations of: (i) transparency, accountability, and associated issues of governance; (ii) the government's flexibility to conduct fiscal policy; (iii) the administrative costs; and (iv) uncertainty.

Secondly, the analysis shows that welfare losses rise more than proportionally with the implicit taxation or subsidization, approximated by the ratio of the curb market exchange rate and the official exchange rate. Thus, the rise of the curb market premium from 100 percent to more than 400 percent inflicts growing efficiency losses on the Uzbek economy, severely undermining the country's ability to utilize its growth potential. From the economic policy point of view, our analysis at a minimum supports the conventional wisdom that the spread between these various exchange rates needs to be reduced, if not eliminated, as soon as possible.

Thirdly, the finding that excess burdens increase more than proportionally in response to an increase in tax or subsidy rates supports even a gradual dismantling of these distortions. If two distortions work in the same direction, the whole is larger than the sum of the parts. That is, the excess burden of the two distortions together is larger than the sum of the two excess burdens measured when each distortion is considered separately. For reform, this means that if only one of several cumulated distortions is removed, the beneficial effect on consumer or producer welfare will be more than proportional. If a gradualist reform approach would ever be effective, it would be in situations like these.

Finally, any reform of the existing foreign exchange regime will also need to take account of the fact that distortions arising from explicit and implicit fiscal operations often work in directions opposite to each other. Examples include:

- Uzbekistan, on the one hand, grants no value-added tax credit for the purchase of capital goods, adding 20 percent to their price; on the other hand, there is an implicit subsidy on imported capital goods of more than 50 percent (for centralized imports) and 40 percent (for other legal imports).

- Until July 2000, imports of sugar and vegetable oil were subsidized through the foreign exchange regime while at the same time both imports were taxed by regressive "import excises" of 20 percent.

- As shown above, there is a large implicit tax on centralized exports of more than 50 percent. At the same time, profits earned by exporting enterprises are taxed at half of the standard rate of 33 percent. In addition, exporters enjoy several other tax exemptions and implicit subsidies. 
The consequences of reform in such situations are not clear a priori. Removing the smallest distortion while leaving the biggest in place would exacerbate, not improve, welfare losses. Removing the biggest while leaving the smallest in place would turn net taxation into net subsidization and vice versa, with an increase in welfare costs if the smallest price distortion was larger than half of the biggest. Therefore, it is essential for fiscal reform to identify distortions that work in opposite directions (like the examples above) and to abolish them simultaneously. ${ }^{17}$ Such reform packages would be superior to step-by-step reform or the elimination of the multiple exchange rate regime alone.

We conclude that the Uzbek authorities should reduce, if not eliminate, the above mentioned explicit and implicit distortions as soon and as simultaneously as possible.

\section{APPENDIX Calculation of the Net Welfare Loss Due to the Foreign Exchange Regime}

The welfare loss (NWL) or excess burden due to Uzbekistan's foreign exchange regime is derived in Rosenberg, Ruocco, and Wiegard (1999). Here we replicate only the case of implicit subsidies. Analogous manipulations apply for the case of implicit export taxes.

Let $P^{M}{ }_{F T}$ denote the fixed world market price and $M_{F T}$ be the import quantity that would result under free trade $(F T)$. By $s u b$ we denote the ad valorem subsidy rate and by $P_{\text {sub }}=P_{F T}^{M_{F T}}$ $(1-s u b)$ the subsidized price for Uzbekistan's importers. $M_{s u b}$ is the corresponding import quantity under the subsidized exchange rate regime. Assuming a constant elasticity import demand function and using the concept of Harberger triangles from their graphical analysis, Rosenberg, Ruocco, and Wiegard (1999) show that for the small country case, the net welfare loss for Uzbekistan due to implicit import subsidies is

$$
\begin{aligned}
N W L_{M} & =\operatorname{subP} P_{F T}^{M} M_{s u b}-\left\{\left[A \int_{0}^{M_{s u b}} M^{-\alpha} d M-P_{s u b}^{M} M_{s u b}\right]-\left[A \int_{0}^{M_{F T}} M^{-\alpha} d M-P_{F T}^{M} M_{F T}\right]\right\} \\
& =\operatorname{sub} P_{F T}^{M} M_{s u b}-\frac{\alpha}{1-\alpha} A M_{\text {sub }}^{1-\alpha}\left[1-\left(\frac{M_{F T}}{M_{\text {sub }}}\right)^{1-\alpha}\right] .
\end{aligned}
$$

From the import demand function (1) in the main text we obtain

$$
\frac{M_{F T}}{M_{s u b}}=\left(\frac{P_{F T}^{M}}{P_{s u b}^{M}}\right)^{-\frac{1}{\alpha}}=\left(\frac{1}{1-s u b}\right)^{-\frac{1}{\alpha}} .
$$

Furthermore, we have

$$
A M_{s u b}^{1-\alpha}=P_{s u b}^{M} M_{s u b}=(1-s u b) P_{F T}^{M} M_{s u b}=\frac{1-s u b}{s u b} s u b P_{F T}^{M} M_{s u b} .
$$

${ }^{17}$ The welfare effects of such tradeoffs were, for example, calculated by Tarr (1990) for Poland in the late 1980s. 
Inserting (ii) and (iii) into (i), and factoring out results in

$$
\frac{N W L_{M}}{s u b P_{F T}^{M} M_{s u b}}=1-\frac{1-s u b}{s u b} \frac{\alpha}{1-\alpha}\left\lceil 1-\left(\frac{1}{1-s u b}\right)^{\frac{\alpha-1}{\alpha}}\right\rceil .
$$

If $\alpha=1$, the derivation is slightly different, but the outcome is basically the same. In this case the primitive function of $\mathrm{M}^{-\alpha}$ is not $M^{1-\alpha} /(1-\alpha)$ but $\ln (M)$, so that $N W L_{M}=\operatorname{sub} P_{F T}^{M} M_{s u b}+A(\ln$ $\left.M_{F T}-\ln M_{s u b}\right)$, or, for that matter, sub $P_{F T}^{M} M_{s u b}+A . \ln \left(M_{F T} / M_{s u b}\right)$.

If $\alpha=1, A=(1-s u b) P_{F T}^{M} . M_{s u b}$, so that $N W L_{M}=\operatorname{sub} P_{F T}^{M} M_{s u b}+A . \ln \left(M_{F T} / M_{\text {sub }}\right)$

$=\operatorname{sub} P_{F T}^{M} M_{s u b}+(1-s u b) P_{F T}^{M} \cdot M_{s u b} \cdot \ln \left(M_{F T} / M_{s u b}\right)$

= (using equation iv) $s u b P_{F T}^{M} M_{s u b}+(1-s u b) . P_{F T}^{M} \cdot M_{s u b} \cdot \ln (1-s u b)$.

This means that

$$
N W L_{M} / s u b P_{F T}^{M} M_{s u b}=\{1+(1-s u b) / s u b\} \ln (1-s u b)
$$

The net welfare losses in Table 5 (and, analogously, in Table 4) are calculated inserting alternative elasticity estimates and the implicit subsidy rates from Table 2. Table A1 shows the

\begin{tabular}{|c|c|c|c|}
\hline \multicolumn{4}{|c|}{ (In millions of U.S. dollars) } \\
\hline & 1997 & 1998 & 1999 \\
\hline Exports & 2,756 & 2,882 & 2,251 \\
\hline Centralized & 2,186 & 2,063 & 1,513 \\
\hline Other & 570 & 819 & 738 \\
\hline Imports & 3,926 & 2,872 & 2,251 \\
\hline Centralized & 2,941 & 1,597 & 905 \\
\hline Other & 985 & 1,275 & 1,346 \\
\hline
\end{tabular}
annual foreign exchange flows used in the calculations.

Sources: CBU; and authors' own calculations. 


\section{REFERENCES}

Agénor, Pierre Richard, and Murat Ucer, 1995, "Exchange Market Reform, Inflation, and Fiscal Deficits," IMF Working Paper 95/73 (Washington: International Monetary Fund, August).

Baliño, Tomás, Adam Bennett, and Eduardo Borensztein, 1999, Monetary Policy in Dollarized Economies, IMF Occasional Paper No. 171 (Washington: International Monetary Fund).

Chepel, Sergei, 1998, "Foreign Currency Policy of Uzbekistan," in Uzbek Economic Trends, ed. by Ministry of Macroeconomics and Statistics, Uzbekistan (October-December), pp. 25-28.

Connolly, Sara, and Alistair Munro, 1999, Economics of the Public Sector (Hemel Hempstead, United Kingdom: Prentice Hall).

International Monetary Fund, 1998, "Republic of Uzbekistan-Recent Economic Developments," IMF Staff Country Report No. 98/116 (Washington: International Monetary Fund, October).

— , 2000, "Republic of Uzbekistan-Recent Economic Developments," IMF Staff Country Report No. 00/36 (Washington: International Monetary Fund, March).

Mackenzie, George A., and Peter Stella, 1996, Quasi-Fiscal Operations of Public Financial Institutions, IMF Occasional Paper No. 142 (Washington: International Monetary Fund).

Reinhart, Carmen, 1995, "Devaluation, Relative Prices, and International Trade," IMF Staff Papers, Vol. 42 (June), pp. 290-312.

Rosenberg, Christoph, Anna Ruocco, and Wolfgang Wiegard, 1999, "Explicit and Implicit Taxation in Uzbekistan," in Herausforderungen an die Wirtschaftspolitik an der Schwelle zum 21. Jahrhundert, Festschrift für Lutz. Hoffmann zum 65. Geburtstag, ed. by Irmgard Nübler and Harald Trabold (Berlin: Duncker und Humbolt), pp. 141-62.

Rosenberg, Christoph, and Maarten de Zeeuw, 2000, “Welfare Effects of Uzbekistan's Foreign Exchange Regime,” IMF Working Paper 00/61 (Washington: International Monetary Fund, March).

Senhadji, Abdelhak S., 1998, "Time-Series Estimation of Structural Import Demand Equations: A Cross-Country Analysis," IMF Staff Papers, Vol. 45 (June), pp. 236-68.

_ , and Claudio Montenegro, 1999, "Time-Series Analysis of Export Demand Equations: A Cross-Country Analysis," IMF Staff Papers, Vol. 46 (September), pp. 259-73.

Tarr, David, 1990, "Second-Best Foreign Exchange Policy in the Presence of Domestic Price Controls and Export Subsidies," World Bank Economic Review, Vol. 4 (May), pp. 175-93.

World Bank, 1999, "Uzbekistan: Social and Structural Policy Review," Report No. 19626 (Washington: World Bank, August). 